\title{
Factors affecting migratory bird routes over the Gulf of Mexico
}

\author{
JOHN H. RAPPOLE and MARIO A. RAMOS
}

\section{Summary}

Over half of the 332 migratory bird species that breed in North America and winter in the tropics are affected by the obstacle to migratory flight presented by the Gulf of Mexico. Landbird migration in the vicinity of the Gulf is considered from an historical perspective, and in light of netting and observational data from the western Gulf coast. A trans-Gulf crossing from the northern Gulf coast to, or over, Yucatán is the most commonly followed fall route for eastern Nearctic migrants that winter in Central America. The spring route for these species is different, involving a more westerly trans-Gulf course for some individuals, and a circum-Gulf route for others. Prevailing wind direction and the probability of meeting turbulence over the Gulf are suggested as the main selective factors affecting route form for Gulf-area migrants.

Aproximadamente la mitad de las 332 especies de aves migratorias que se reproducen en Norte América e invernan en los trópicos son afectadas durante su vuelo migratorio por el obstáculo que representa el Golfo de México. La migración terrestre siguiendo la costa del Golfo de México es considerada desde una perspectiva histórica y a la luz de los datos de observaciones y uso de redes de la costa occidental del Golfo. La ruta migratoria cruzando el Golfo de México hasta o a través de la península de Yucatán es la ruta más comúnmente seguida durante el otoño por los migrantes neárticos del este que invernan en Central América. La ruta durante la primavera para estas especies es diferente; involucra una ruta mas occidental a través del Golfo para algunas de estas especies, o una ruta siguiendo la costa para otras especies. La dirección prevaleciente del viento y la probabilidad de encontrar turbulencias sobre el Golfo se sugieren como los principales factores que pueden afectar la ruta migratoria en el área del Golfo.

\section{Introduction}

The migration route is a significant part of a species's range. Selection pressures faced by the individual during migration are as important in determining fitness as those faced on the wintering or breeding grounds. Yet the ephemeral nature of migration routes makes them difficult to study. Routes for various species have been pieced together from fragments of information gathered by sundry researchers using different techniques at various levels of expertise. Nevertheless, pub- 
lished representations of routes (e.g. those in Cooke 1915, Lincoln 1950, Fisher 1979) tend to assume a certainty far transcending the data that went into their construction. If present-day migration routes had been formed tens of millions of years in the past as suggested by Wolfson (1948), their structure might be of little concern, except perhaps to paleogeographers. Evidence of several kinds indicates that this is not the case. Migration routes are subject to continuous modification (i.e. evolution) through natural selection according to changes in a variety of selection pressures (Rappole et al. 1979, Richardson 1979).

This paper is a re-examination of the question of whether a large portion of avian migrants that breed in temperate North America and winter in Central America normally cross the Gulf of Mexico (trans-Gulf migration), go around it (circum-Gulf migration), or use some combination of these two strategies/ options.

The Gulf migration system has been studied intensively for more than a century. However, route selection theories proposed to date do not explain the information available on migrants in the Gulf region (Lowery 1945, 1946, 1951, Williams 1945, reports in Audubon Field Notes and American Birds, passim). The analysis presented herein was undertaken for this reason and because of the Gulf's importance as a major route for many Nearctic migrants.

\section{History}

The Gulf of Mexico and the Caribbean Sea have been and remain critical areas for the study of migration routes. Many of the Nearctic migrants that breed in eastern North America occur regularly somewhere in these areas at some time during migration. Cooke (1915) proposed five major routes for eastern Nearctic transients, based on limited ground survey data, shipboard observation reports and lighthouse kills: (1) Island Route - Florida peninsula to the island chain of the Greater and Lesser Antilles to South America; (2) Bobolink Route - Florida to Cuba and across the Caribbean to South America; (3) Shorebird Route north-east coast of North America nonstop over the western North Atlantic to South America; (4) Western Gulf Route (circum-Gulf migration) - along the Gulf coast of Texas and Mexico to Central America; (5) Gulf Route (trans-Gulf) northern Gulf coast across the Gulf to Central America. Cooke believed that the trans-Gulf route (Figure 1 ) was the main fall and spring path followed by eastern Nearctic transients that winter in Central America. Although he was aware that members of some species followed a different route north from that taken south, he apparently felt that deviation of this type was exceptional and that most birds follow the same route in both directions.

Cooke's explanation of the few data available remained undisputed for nearly half a century, although distributional data far in excess of those available in Cooke's time were accumulated. When Williams (1945) challenged Cooke's trans-Gulf theory, he was considered as something of a heretic (see Lincoln's preface to Lowery 1946). Williams attacked the hypothesis on two points. First, he pointed out that the volume of circum-Gulf migration, particularly in spring, was much greater for supposedly trans-Gulf species than Cooke had realized. Second, he maintained that the data supporting the trans-Gulf theory were 


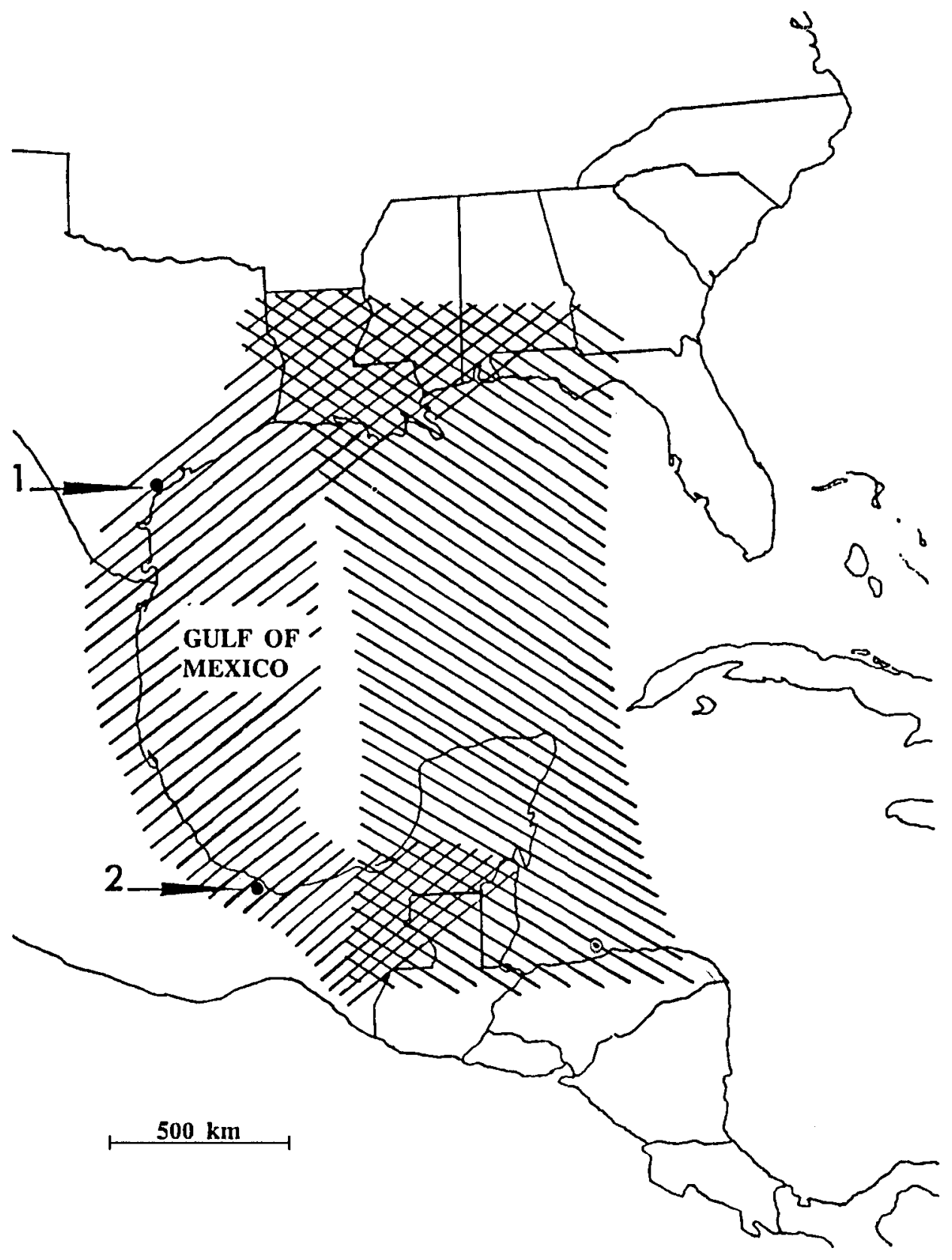

Figure 1. Circum-Gulf (upper right to lower left hatching) versus trans-Gulf (upper left to lower right hatching) migration routes (Texas and Veracruz study sites shown at 1 and 2, respectively). Note that the "circum-Gulf" route is actually a western trans-Gulf route with a strong circum-Gulf component. 
open to interpretation. Williams proposed that a circum-Gulf spring route better explained the available data (Figure 1 ).

Ironically Lowery, unaware of William's paper, published an article in the same year in which he presented evidence that supported the trans-Gulf hypothesis almost incidentally (see editor's note in Lowery 1945). A year later, Lowery (1946) presented a rebuttal of Williams' circum-Gulf hypothesis. He based his arguments mostly on migrant survey data from the northern Gulf coast, shipboard observations of migrants over the Gulf, and some Yucatán sightings.

The exchange between Lowery and Williams continued over a period of years (Williams 1947, 1950, Lowery 1951). Ultimately, Stevenson (1957), using the results of various surveys of migrant density from Florida to Yucatán, appeared to have resolved the dispute largely in favour of Lowery and Cooke. His data showed that while some species followed a circum-Gulf spring route, these were far outnumbered by those following a trans-Gulf route. Gauthreaux (1971) further strengthened this viewpoint, presenting radar data to document the actual volume of migrants arriving off the Gulf at coastal Louisiana. This and similar research reduced Williams's dispute with Lowery to the level of a historical curiosity of seemingly little relevance to current scientific thought.

At present, the theory that the majority of trans-Gulf migrants follow the same route across the Gulf in spring as they do in fall seems to have made the transition from hypothesis to accepted fact. Yet observers continue to report annual spring volumes of supposedly trans-Gulf migrants along the coasts of Texas and Veracruz far in excess of what one would expect according to the trans-Gulf theory (Forsyth and James 1971, Cottam and Blacklock 1972, Blacklock 1976, Rappole et al. 1979). These data raise some questions concerning the accuracy of the theory, at least in its present form.

\section{Comparisons of migration volume: Texas, Veracruz, Louisiana and Florida}

Studies of landbird migrants were conducted during migration seasons from fall 1973 to spring 1975 at two sites $1,1003 \mathrm{~km}$ apart on the western coast of the Gulf of Mexico. One site was located $200 \mathrm{~km}$ south-east of Veracruz City in the Tuxtla Mountains of southern Veracruz, Mexico; the other at the Welder Wildlife Foundation, $41 \mathrm{~km}$ north of Corpus Christi, Texas (Figure 1). Most of the data collected at these sites have been presented elsewhere (Rappole 1976, 1978, Rappole and Warner 1976, 1980, Rappole et al. 1979).

Relative abundances from the Texas and Veracruz sites for supposed transGulf migrants (Stevenson 1957) are compared in Table 1 with abundance estimates for the same species from Louisiana (Lowery 1955) and Florida (Sprunt 1974). Though the methods of data collection used in our studies (mist-netting) versus those used in the regional works (visual observation) are not strictly comparable, both techniques reflect actual abundance pattern on a gross scale (common, uncommon, rare). This contention is supported by the fact that abundance estimates from netting in Texas are comparable to those based on long-term visual observations in the same area (Blacklock 1976).

The abundance comparisons shown in Table 1 illustrate a number of regional contrasts in migrant abundance. Half of the species listed are either uncommon 
Table 1 . Comparison of seasonal abundances ${ }^{1}$ from Veracruz ${ }^{2}$, Texas ${ }^{2}$ and Louisiana ${ }^{3}$ for species considered by Stevenson (1957) to be mainly migrants across the central Gulf in spring

\begin{tabular}{|c|c|c|c|c|c|c|}
\hline \multirow[t]{3}{*}{ Species } & \multicolumn{6}{|c|}{ Abundances ${ }^{1}$} \\
\hline & \multicolumn{3}{|c|}{ Fall } & \multicolumn{3}{|c|}{ Spring } \\
\hline & VER $^{2}$ & $\mathrm{TX}^{2}$ & $\mathrm{LA}^{3}$ & VER & $\mathrm{TX}$ & $\mathrm{LA}$ \\
\hline $\begin{array}{l}\text { Acadian Flycatcher } \\
\text { Empidonax virescens }\end{array}$ & - & o & + & + & + & + \\
\hline $\begin{array}{l}\text { Least Flycatcher } \\
\text { Empidonax minimus }\end{array}$ & W & 0 & + & W & 0 & + \\
\hline $\begin{array}{l}\text { Eastern Wood Pewee } \\
\text { Contopus virens }\end{array}$ & + & 0 & + & W & + & + \\
\hline $\begin{array}{l}\text { Grey Catbird } \\
\text { Dumetella carolinensis }\end{array}$ & W & o & + & W & + & + \\
\hline $\begin{array}{l}\text { Wood Thrush } \\
\text { Hylocichla mustelina }\end{array}$ & W & $\mathrm{O}$ & + & $\mathrm{W}$ & + & + \\
\hline $\begin{array}{l}\text { Swainson's Thrush } \\
\text { Catharus ustulatus }\end{array}$ & o & o & + & + & + & + \\
\hline $\begin{array}{l}\text { Grey-cheeked Thrush } \\
\text { Catharus minimus }\end{array}$ & - & - & + & o & + & + \\
\hline $\begin{array}{l}\text { Veery } \\
\text { Catharus fuscescens }\end{array}$ & - & - & + & 0 & 0 & 0 \\
\hline $\begin{array}{l}\text { Red-eyed Vireo } \\
\text { Vireo olivaceus }\end{array}$ & - & 0 & + & 0 & + & + \\
\hline $\begin{array}{l}\text { Warbling Vireo } \\
\text { Vireo gilvus }\end{array}$ & - & 0 & + & - & 0 & + \\
\hline $\begin{array}{l}\text { Black-and-white Warbler } \\
\text { Mniotilta varia }\end{array}$ & W & + & + & W & + & + \\
\hline $\begin{array}{c}\text { Prothonotary Warbler } \\
\text { Protonotaria citrea }\end{array}$ & - & 0 & + & - & o & + \\
\hline $\begin{array}{l}\text { Worm-eating Warbler } \\
\text { Helmitheros vermivorus }\end{array}$ & W & - & 0 & $W$ & + & o \\
\hline $\begin{array}{l}\text { Tennessee Warbler } \\
\text { Vermivora peregrina }\end{array}$ & o & 0 & + & 0 & + & + \\
\hline $\begin{array}{l}\text { Magnolia Warbler } \\
\text { Denároica magnolia }\end{array}$ & W & 0 & + & W & + & + \\
\hline $\begin{array}{l}\text { Blackburnian Warbler } \\
\text { Dendroica fusca }\end{array}$ & - & - & + & 0 & + & + \\
\hline $\begin{array}{l}\text { Chestnut-sided Warbler } \\
\text { Dendroica pensylvanica }\end{array}$ & - & - & + & + & + & + \\
\hline $\begin{array}{c}\text { Bay-breasted Warbler } \\
\text { Dendroica castanea }\end{array}$ & - & - & + & o & + & + \\
\hline $\begin{array}{l}\text { Ovenbird } \\
\text { Seiurus aurocapillus }\end{array}$ & W & 0 & + & $W$ & + & + \\
\hline $\begin{array}{l}\text { Northern Waterthrush } \\
\text { Seiurus noveboracensis }\end{array}$ & $W$ & 0 & + & $W$ & + & + \\
\hline $\begin{array}{l}\text { Louisiana Waterthrush } \\
\text { Seiurus motacilla }\end{array}$ & $W$ & - & 0 & $W$ & 0 & 0 \\
\hline $\begin{array}{l}\text { Kentucky Warbler } \\
\text { Oporornis formosus }\end{array}$ & W & 0 & + & + & + & + \\
\hline $\begin{array}{l}\text { Hooded Warbler } \\
\text { Wilsonia citrina }\end{array}$ & $W$ & - & + & + & + & + \\
\hline $\begin{array}{l}\text { Summer Tanager } \\
\text { Piranga rubra }\end{array}$ & W & - & + & + & $o$ & + \\
\hline $\begin{array}{c}\text { Rose-breasted Grosbeak } \\
\text { Pheucticus ludovicianus }\end{array}$ & - & - & + & - & o & + \\
\hline
\end{tabular}

1+, Common; o, Uncommon; -, Rare; W, Winter in Veracruz. ${ }^{2}$ Veracruz and Texas abundances are based on the following scale: Common 10.1 birds or more captured per 10,000 net hours; Uncommon, 1.1-10.0; Rare, less than 1.0. One net hour, one $12 \mathrm{~m} \times 2.6 \mathrm{~m}$ net open for one hour. ${ }^{3}$ Based on Lowery (1955). 


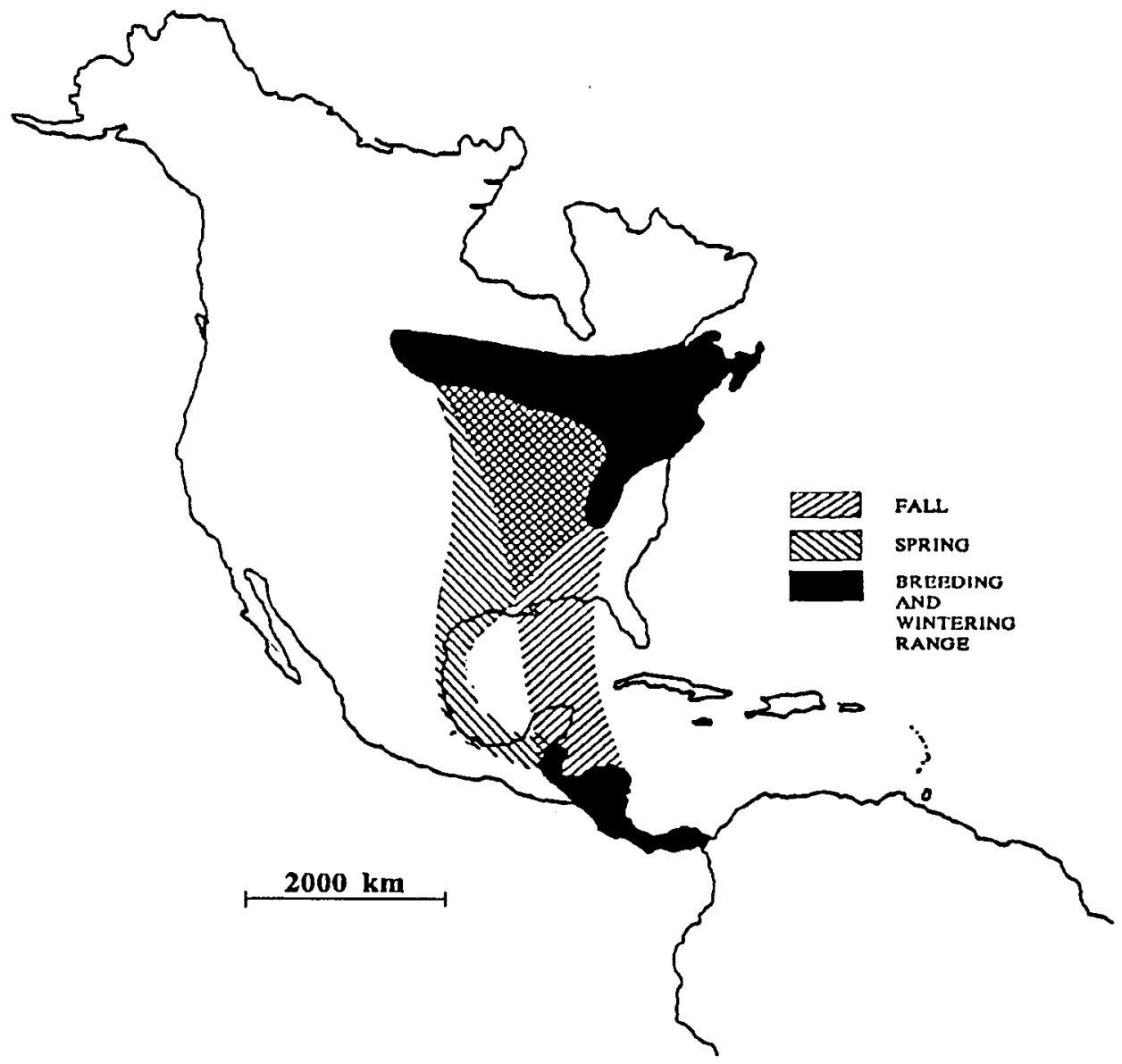

Figure 2. Fall versus spring, Gulf-area migration routes for a "typical" Nearctic migrant.

or rare in Texas on the west, but common in Louisiana. Furthermore, all but four of the species are less common in Texas during fall than in the spring. Both of these comparisons indicate that, for most of these birds, the bulk of fall migration is trans-Gulf, with points of departure concentrated along the northern Gulf coast.

The spring data provide a striking contrast to the fall data quoted above. All but four species shown are commoner along the Texas central coast in spring than in fall. The same pattern is seen in Veracruz for those species that winter south of the Veracruz study site (e.g. Grey-cheeked Thrush Catharus minimus and Blackburnian Warbler Dendroica fusca). These comparisons indicate that the spring migration route is skewed considerably to the west for individuals of many trans-Gulf species.

Figure 2 shows a migration pathway for a population of "typical" eastern Nearctic migrants that winter in Central America, as reconstructed from the comparisons shown in Table 1 . From this figure it is possible to understand how Lowery (1946) and Williams (1945) could have come to adopt apparently 
opposing theories concerning the form of this route: from Texas the circum-Gulf aspect is obvious, while from Louisiana the trans-Gulf aspect is clear.

\section{Discussion}

Although not all of the species shown in Table 1 fit the pattern outlined in Figure 2, there does appear to be a general trend in a number of species of Nearctic-breeding migrants that winter in Central America to cross the eastern Gulf of Mexico in fall, and to follow a more westerly trans-Gulf route or circumGulf route, paralleling the coasts of Veracruz and Texas, in spring. Possible reasons behind this pattern become apparent when the meteorological peculiarities of the Gulf region are considered.

The most obvious fact affecting a route is the relative location of breeding and wintering areas. If no other factors affect the bird, it should take the most direct route possible between its seasonal homes. Given this basic premise, deviations from a direct route must reflect the effect of selection pressures during a migration journey. Along with obstacles and barriers (oceans, mountains, deserts), wind direction must be considered as a major factor affecting migration movement (Able 1974). Richardson (1979) has suggested that the wind patterns over the western North Atlantic are responsible for elliptical migration routes taken by many shorebirds. Members of these species follow a western North Atlantic route to South America in fall (Williams et al. 1977), but follow a much more westerly Caribbean or Gulf route north in spring.

During fall in the Gulf region, the most favourable winds for southward migrations occur in the wake of fronts, when winds are from the north (Able 1972) (Figure 3). In spring, the most favourable winds for northward migration occur during periods when stationary highs are centred off the east coast of Florida (Gauthreaux 1971) (Figure 4). Winds over the Gulf under these conditions are from the south-east or east. Since birds tend to fly downwind during migration (Able 1974), prevailing wind direction alone could account for at least part of the more westward swing seen in spring vs. fall migration, in the Gulf area as well as in other areas (Lowery 1951). However, wind direction is probably only a partial reason for the westward skew of the spring route. Another, perhaps more important selective factor in this case is relative weather quality. Buskirk (1980) and Rappole et al. (1979) have pointed out that weather over the Gulf probably affects timing of migratory movements. It almost certainly affects the choice of route as well, in an evolutionary sense.

In fall, the migrants often follow fronts over the Gulf when the weather ahead of them is predictable and moving in roughly the same direction and at comparable speeds to the birds. The probability of confronting a broad area of turbulence on a trans-Gulf trip is low. Frontal systems usually move in a general north-west to south-east direction in this region (Figure 3).

In spring, the birds do not follow fronts when crossing the Gulf. The fronts still come down from the north and north-west, but a bird departing on a trans-Gulf flight from Yucatán north toward the Louisiana coast cannot anticipate whether or not it will run into a front coming south at some point over open water. As a result, those birds that do attempt a trans-Gulf spring flight can 


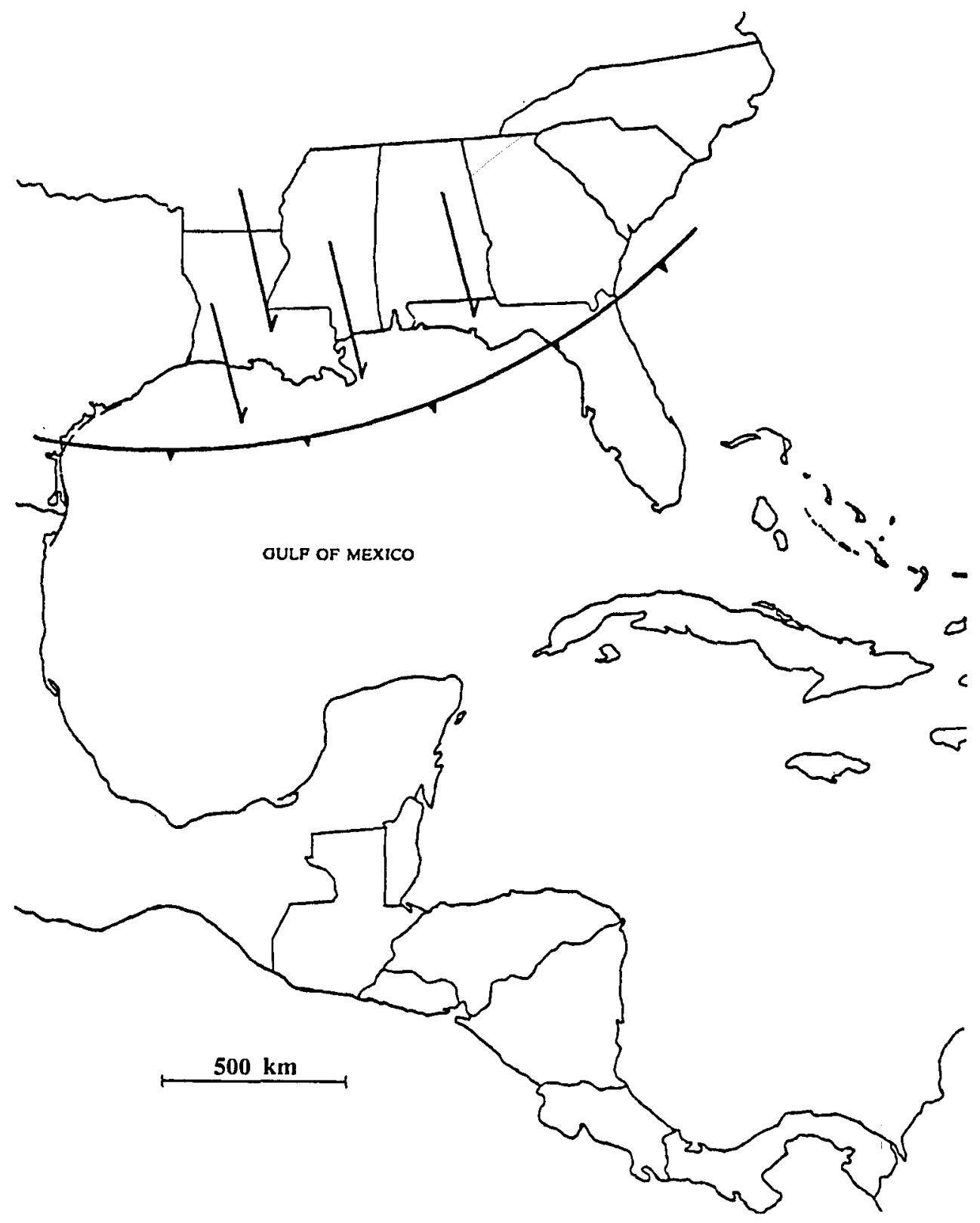

Figure 3. Wind direction (arrows) in the wake of a frontal system over the northern Gulf coast.

and occasionally do meet fronts over the Gulf. When this occurs, the results can be disastrous, causing delays of 12-20 hours in northern Gulf landfall and, probably, high mortality. Gauthreaux (1971) found that there were fronts over the Gulf on $16 \%$ of the nights for which he had data during the peak of spring migration (April 8-May 15). Clearly, this kind of weather system could act as a major selection force shaping northward routes of small, normally trans-Gulf 


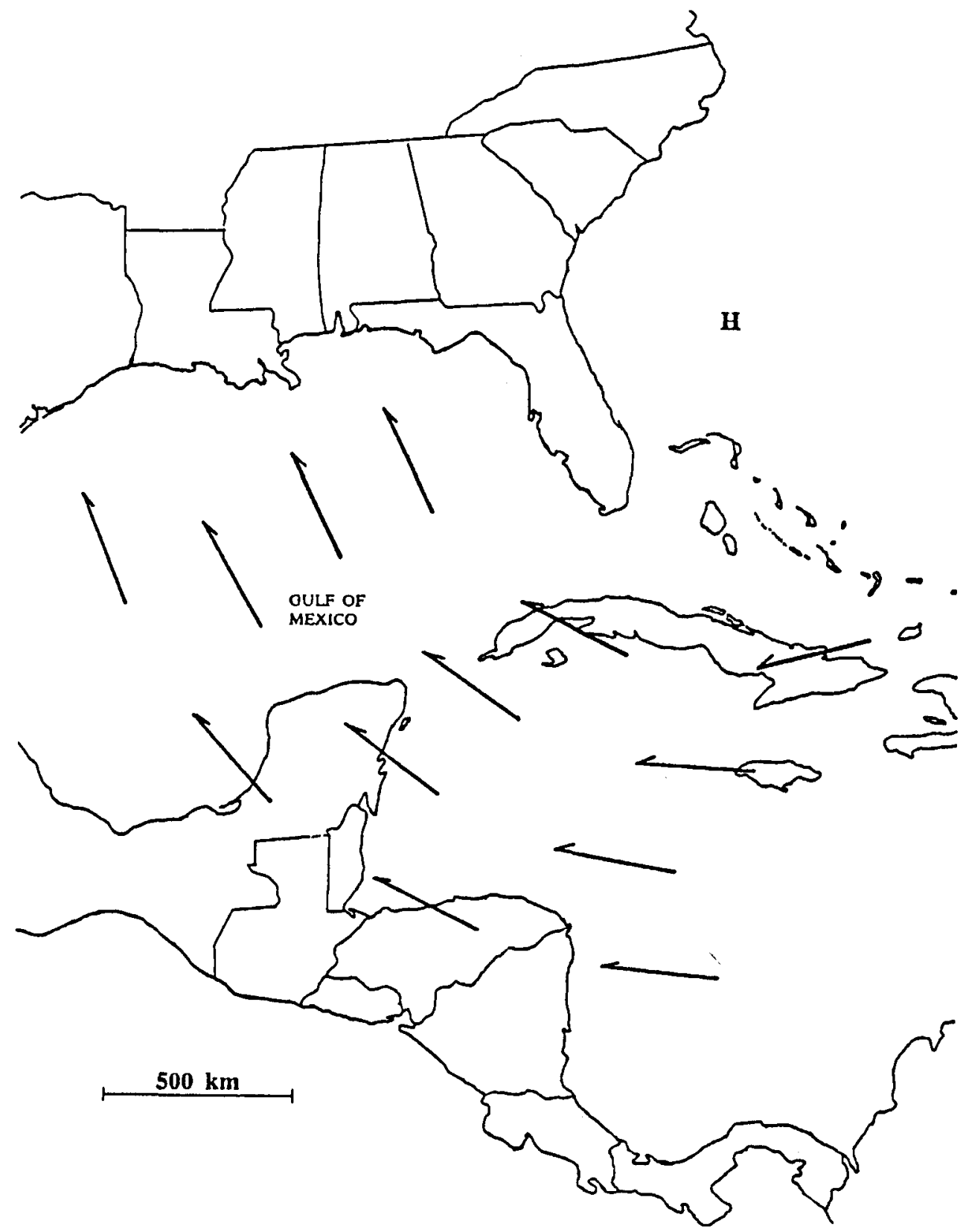

Figure 4. Prevailing wind direction (arrows) over the Gulf of Mexico when a high pressure system $(H)$ is situated off the Florida Atlantic coast.

migrants, thus favouring a more circuitous but considerably safer route over the western Gulf or along the coast (Ganier 1944).

This hypothesis could also explain the sudden appearance of grounded migrants along the immediate coast of the western Gulf at the onset of a frontal system where no migrants had previously been observed on the ground or in 
the air - a phenomenon noted by Attwater (1892), Williams (1945), James (1956), Forsyth and James (1971) and many others familiar with weather and spring migrations along the Texas Gulf coast. Birds flying a route paralleling the western Gulf shore, but flying many kilometres out to sea, should be able to see fronts approaching from the north and make landfall along the Gulf coast within one to two hours.

\section{Conclusions}

As Cooke (1915), Lowery (1946) and many other researchers have long maintained, most migrants that breed in the eastern Nearctic and winter in Central America are trans-Gulf travellers in fall, and many follow a trans-Gulf route in spring. However, as Williams (1945) argued, many of these same birds that were trans-Gulf migrants in fall follow a more westerly trans-Gulf or circumGulf route in spring. We have suggested that the direction of prevailing winds and the likelihood of confronting turbulence over the Gulf are probably important factors shaping this particular portion of the migration route, through the process of natural selection. That other selection factors are involved that are more closely related to the specific ecology and physiology of individuals within a particular species is certain (Morton 1971, Phillips 1975, Harrington and Morrison 1979). These factors are extremely difficult to document, requiring both long-term study of migrant ecology at stopover points and accurate distributional data from broad geographical areas. Yet the need for studies of this kind is evident. Given the ability of man to alter significant portions of the environment, the migrant is especially vulnerable, dependent as it is on environments tens, hundreds and thousands of kilometres apart. Stopover points in Texas and Veracruz and weather over the Gulf of Mexico may be as important to populations of a Nearctic migrant as breeding habitat in New York or wintering habitat in Costa Rica. Life history studies and efforts at conservation must take this fact into consideration: failure to do so is to ignore a critical part of migrant biology and life history.

\section{Acknowledgements}

We thank Bonnie Rappole, Chris Barkan, Bruce Fall, Dwain Warner and Robert Zink for help with fieldwork and for discussions during the course of the study. We thank the Directors and Trustees of the Welder Wildlife Foundation for financial support.

\section{References}

Able, K. P. (1972) Fall migration in coastal Louisiana and the evolution of migration patterns in the Gulf region. Wilson Bull. 84: 231-242.

Able K. P. (1974) Environmental influences on the orientation of free-flying nocturnal migrants. Anim. Behav. 22: 224-238.

Attwater, H. P. (1892) Warblers destroyed by a "norther". Auk 9: 303.

Blacklock, G. W. (1976) Checklist of the birds: central coast of Texas. Corpus Christi, Texas: Corpus Christi Museum Guild. 
Buskirk, W. H. (1980) Influence of meteorological patterns and trans-Gulf migration on the calendars of migrants to the Neotropics. Pp.485-493 in A. Keast and E. S. Morton, eds. Migrant birds in the Neotropics: ecology, behavior, distribution, and conservation. Washington, D.C.: Smithsonian Institution Press.

Cooke, W. W. (1915) Bird migration. U.S. Dept. Agr. Bull. no.185.

Cottam, E. and Blacklock, G. W. (1972) Checklist of the birds: Welder Wildlife Foundation (San Patricio County, Texas). Sinton, Texas: Welder Wildlife Foundation.

Fisher, A. C. (1979) Mysteries of bird migration. Natn. Geogr. Mag. 156: 154-173.

Forsyth, B. J. and James, D. (1971) Springtime movements of transient nocturnally migrating landbirds in the Gulf coastal bend region of Texas. Condor 73: 193-207.

Ganier, A. F. (1944) Maps showing Chimney Swift migration. Migrant 15: 44.

Gauthreaux, S. A. (1971) A radar and direct visual study of passerine spring migration in southern Louisiana. Auk 88: 343-365.

Harrington, B. A. and Morrison, R. I. G. (1979) Semipalmated sandpiper migration in North America. Stud. Avian Biol. 2: 83-100.

James, P. (1956) Destruction of warblers on Padre Island, Texas, in May, 1951. Wilson Bull. 68: 224-227.

Lincoln, F. E. (1950) Migration of birds. U.S. Department of Interior (Fish and Wildlife Service Circular 16).

Lowery, G. H. (1945) Trans-Gulf spring migration of birds and the coastal hiatus. Wilson Bull. 57: 92-121.

Lowery, G. H. (1946) Evidence of trans-Gulf migration. Auk 63: 175-210.

Lowery, G. H. (1951) A quantitative study of nocturnal migration of birds. Univ. Kansas Publ., Mus. Nat. Hist. 3: 361-472.

Lowery, G. H. (1955) Louisiana birds. Baton Rouge, Louisiana: Louisiana State University.

Morton, E. S. (1971) Food and migration habits of the Eastern Kingbird in Panama. Auk 88: $925-926$.

Phillips, A. R. (1975) The migration of Allen's and other hummingbirds. Condor 77: 196205.

Rappole, J. H. (1976) A study of evolutionary tactics in populations of solitary avian migrants. Minneapolis, Minnesota: University of Minnesota (Ph.D. dissertation).

Rappole, J. H. (1978) Seasonal distribution notes on birds from the Welder Refuge, San Patricio County, Texas. Bull. Texas Orn. Soc. 11: 30-34.

Rappole, J. H., Ramos, M. A., Oehlenschlager, R. J., Warner, D. W. and Barkan, C. P. (1979) Timing of migration and route selection in North American songbirds. Pp.199214 in D. L. Drawe, ed. Proc. First Welder Wildlife Foundation Symposium. Sinton, Texas: Welder Wildlife Foundation.

Rappole, J. H. and Warner, D. W. (1976) Relationships between behavior, physiology and weather: avian transients at a migration stopover site. Oecologia 26: 193-212.

Rappole, J. H. and Warner, D. W. (1980) Ecological aspects of avian migrant behavior in Veracruz, Mexico. Pp.353-393 in A. Keast and E. S. Morton, eds. Migrant birds in the Neotropics: ecology, behavior, distribution, and conservation. Washington, D.C.: Smithsonian Institution Press.

Richardson, W. J. (1979) South-eastward shorebird migration over Nova Scotia and New Brunswick in autumn: a radar study. Canad. J. Zool. 57: 107-124.

Sprunt, A. (1974) Florida bird life. New York: Coward-McCann.

Stevenson, H. M. (1957) The relative magnitude of the trans-Gulf and circum-Gulf spring migrations. Wilson Bull. 69: 39-77.

Williams, G. G. (1945) Do birds cross the Gulf of Mexico in spring? Auk 62: 92-111.

Williams, G. G. (1947) Lowery on trans-Gulf migration. Auk 64: 217-238.

Williams, G. G. (1950) The nature and causes of the coastal hiatus. Wilson Bull. 62: 175182.

Williams, T. C., Williams, J. M., Ireland, L. C. and Teal, J. M. (1977) Autumnal bird migration over the western North Atlantic Ocean. Amer. Birds 31: $25^{1-267}$. 
Wolfson, A. (1948) Bird migration and the concept of continental drift. Science 108: 23-30.

JOHN H. RAPPOLE

Conservation and Research Center, National Zoological Park, Smithsonian Institution, Front Royal, VA 22630, U.S.A.

\section{MARIO A. RAMOS}

World Wildlife Fund U.S., 1250 24th Street NW, Washington, D.C. 20037, U.S.A.

Current address: Global Environment Facility, The World Bank, $1818 \mathrm{H}$ Street NW, Washington, D.C. 20433 , U.S.A. 